\title{
ANALISIS MODAL SOSIAL DAN KOMPENSASI TERHADAP KESEJAHTERAAN RUMAH TANGGA (STUDI KASUS RUMAH TANGGA RESETTLEMENT DI SUMATERA BARAT)
}

\author{
Arie Sukma $^{1}$, Fery Andrianus ${ }^{2}$, Syafruddin Karimi $^{i}$ \\ Program Pascasarjana Fakultas Ekonomi Unand \\ asukma@gmail.com, feryandrianus@eb.unand.ac.id, syafruddinkarimi@gmail.com
}

\begin{abstract}
One of the objectives of involuntary resettlement is to improve household welfare, not to make households poor. But in fact, many involuntary resettlement programs make household life no better than before. To assess the condition of household welfare, the happiness indicator is used which consists of 10 indicators. This study used a sample of 100 households in two villages, namely Tanjung Balik and Tanjung Pauh, Pangkalan Koto Baru District, 50 Kota District, West Sumatra Province. In this study, compensation and social capital are two variables that affect household welfare. The compensation received is the initial condition of the displaced households to construct their new life. Then, social capital also greatly affects the condition of household welfare. The results of the structural equation model (SEM) analysis show that compensation has a positive effect on household welfare while social capital has no effect.
\end{abstract}

Key words: involuntary resettlement, compensation, social capital

Abstrak : Salah satu tujuan involuntary resettlement adalah untuk meningkatkan kesejahteraan rumah tangga bukan untuk membuat rumah tangga menjadi miskin. Namun faktanya, banyak program involuntary resettlement membuat kehidupan rumah tangga tidak lebih baik dari sebelumya. Untuk mengkaji kondisi kesejahteraan rumah tangga digunakan indikator kebahagian yang terdiri dari 10 indikator. Penelitian ini menggunakan sampel sebanyak $100 \mathrm{KK}$ di dua desa yaitu Tanjung Balik dan Tanjung Pauh, Kecamatan Pangkalan Koto Baru Kabupaten 50 Kota Provinsi Sumatera Barat. Dalam penelitian ini kompensasi dan modal sosial merupakan dua variabelyang berpengaruh terhadap kesejahteraan rumah tangga. Kompensasi yang diterima merupakan kondisi awal dari rumah tangga yang dipindahkan untuk menkonstruksi kehidupan mereka yang baru. Kemudian, modal sosial juga sangat mempengaruhi kondisi kesejahteraan rumah tangga.Hasil analisis structural equation model (SEM) menunjukkan bahwa kompensasi berpengaruh positif terhadap kesejahteraan rumah tangga sedangkan modal social tidak berpengaruh.

Kata kunci: involuntary resettlement, kompensasi, modal sosial

\section{A. PENDAhULUAN}

Pembangunan bendungan menyebabkan terjadi perubahan kehidupan bagi rumah tangga terkena dampak, dan secara umum banyak penelitian menunjukkan bahwa dampak yang terjadi adalah negatif. (ADB,1995; JBIC , 2004; Kementrian PU, 2011). Dampak negatif yang terjadi merupakan keniscayaan, karena pemerintah sudah melakukan banyak melaksanakan program pembangunan kembali (involuntary resettlement) yang 
bertujuan untuk mengembalikan kembali kehidupan masyarakat minimal sama dengan kondisi sebelumnya atau lebih baik, namun yang terjadi secara umum kehidupan mereka tidak lebih dari sebelumnya di lokasi yang baru. Kondisi ini menjadi pertanyaan kenapa hal ini bisa terjadi. Penelitian ini mencoba mencari jawaban pertanyaan tersebut.

Kondisi yang terjadi seperti disebutkan sebelumnya, tidak terlepas dari peran pemernitah dalam merencanakan dan mempersiapkan program resettlement.Cernea (2004), menjelasakan tanpa bantuan yang cukup dan program yang terencana dengan baik, kehidupan masyarakat yang pindah tidak akan lebih baik bahkan akan terjadi pemiskinan. Hal yang sama disampaikan Asthana (1996), bahwa pemukiman kembali tidak terlepas dari kegiatan menggusur dan membangun kembali kehidupan masyarakat, dan faktaya kehidupan masyarakat tidak lebih baik. Kondisi yang sama juga ditemukan Yasuyuki (1998), penelitian di Nagari Tanjung Pauh menemukan terjadinya penurunan sumber daya dan akses terhadap mata pencarian penduduk yang bekerja sebagai petani. Ganti rugi yang dijanjikan sebelum pindah yang menjadi harapan bagi penduduk tidak diterima masyarakat. Hal yang sama juga ditemukan Uslaini dan Purwanto (2015), kondisi kehidupan mereka tidak lebih baik dari sebelumnya karena mereka kehilangan aset dan tempat tinggal. Kondisi ini sekaligus menunjukkan bahwa proses pemiskinan terjadi di daerah Koto Panjang, paling tidak kondisi ini dirasakan pada masa awal pemindahan penduduk.

Secara teori menurut ADB (1995) seharusnya kehidupan masyarakat yang dipindahkan harus sama atau lebih baik dari sebelumnya, karena masyarakat diberi kompensasi. Kompensasi atau ganti rugi ini mutlak diberikan. Namun demikian, faktanya kompensasi yang dilakukan program pemerintah hanya fokus pada ganti rugi tanah dan pembangunan kembali secara fisik (Kementrian PU, 2011; ADB, 1995). Hal ini tidak berdampak cukup signifikan terhadap kehidupan masyarakat ditempat yang baru, menurut Amiany dan Sahay (2011),kebijakan pemukiman kembali bukan seharusnya bukan hanya fokus pada penggantian kerugian harta atau pembangunan fisik semata, tetapi hal yang lebih penting dilakukan oleh pemerintah adalah langkah-langkah untuk memulihkan taraf hidup dan mata pencaharian (livelihood), bahkan World Bank (2000), menegaskan bahwa kompensasi harus memadai dan tepat waktu, karena hal ini sangat urgen untuk kehidupan resettler.

Resettlement juga berdampak berdampak terhadap modal sosial yang ada ditengah masyarakat.Modal sosial tersebut mengalami perubahan setelah rumah tangga pindah ke tempat yang baru. Hasil penelitian Winter (2000) menunjukkan bahwa modal sosial dapat mempengaruhi kestabilan dan kemandirian keluarga. Kondisi ini sejalan denganpenelitian Cahyono dan Adhiatma (2012) bahwa nilai-nilai kepercayaan sangat berpengaruh untuk dijadikan modal dalam peningkatan kesejahteraan masyarakat.

Studi Karimi dan Taifur (2013) menemukan bahwa terjadi peningkatan kesejahteraan penduduk yang dimukimkan kembali di Provinsi Riau, tetapi peningkatan kesejahteraan penduduk masih diukur dengan variabel material (indikator Objektif).Oleh sebab itu penelitian yang memasukan indikatorobjektif dan subjektif untuk menentukan tingkat kesejahteraan masyarakat rumah tanggapemukiman baru perlu dilaksanakan, untuk mendapatkan hasil yang lebih komprehensif dan mendekati kondisi yang sebenarnya (Andrianus, 2016). 


\section{Permasalahan}

Perumusan masalah dalam penelitian ini adalah:

a. Bagaimana kondisi atau tingkat kesejahteraan rumah tangga yang ikut program pemukiman kembali pembangunan bendungan Koto Panjang di Desa Tanjung Pauh dan Tanjung Balik Kecamatan Pangkalan Koto Baru Kabupaten Lima Puluh Kota Provinsi Sumatera Barat, bagaimana kesejahteraan mereka pada awal pindah dan pada saat sekarang apakah meningkat atau tidak, apakah proses pemiskinan (impoverishment) terjadi atau tidak.

b. Bagaimana kompensasi yang mereka terima, apakah sesuai dengan yang dijanjikan atau tidak

c. Bagaimana kondisi modal sosial yang ada pada masyarakat apakah terjadi perubahan atau tidak setelah mereka dipindahkan

d. Apakah kompensasi dan modal sosial berpengaruh terhadap kesejahteraan rumah tangga yang dipindahkan atau tidak.

\section{Tujuan}

Tujuan penelitian ini adalah

a. Mengkaji bagaimana kesejahteraan rumah pada awal pemindahan dan saat sekarang.

b. Mengkajipengaruh kompensasi dan modal sosialterhadap kesejahteraan rumah tangga

c. Merekomendasikan model dan kebijakan pemukiman kembali yang relevan untuk peningkatan kesejahteraan rumah tangga.

\section{B. METODOLOGI PENELITIAN}

a. Sampel, Lokasi dan Waktu Penelitian

Sampel yang digunakan dalam penelitian ini diambil dari populasi jumlah rumah tangga yang ada di dua desa. Desa yang dijadikan lokasi penelitian merupakan desa yang dipindahkan akibat pembangunan bendungan Koto Panjang.Daerah yang dijadikan lokasi penelitian meliputi 2 (dua) desa atau nagari di Kecamatan Pangkalan Koto Baru yaitu Nagari Tanjung Pauh dan Nagari Tanjung Balik.

Tabel 1. Daerah Penelitian dan Jumlah Responden

\begin{tabular}{|c|c|c|c|}
\hline No & Desa/Kelurahan & KK & Kec/Kab/Prov \\
\hline 1 & Nagari Tanjung Balik & 50 & \multirow{2}{*}{$\begin{array}{c}\text { Kecamatan Pangkalan Koto Baru } \\
\text { Kabupaten } 50 \text { Kota Provinsi } \\
\text { Sumatera Barat }\end{array}$} \\
\hline 2 & Nagari Tanjung Pauh & 50 & \\
\hline & Total & 100 & \\
\hline
\end{tabular}

\subsection{Analisis SEM -PLS}

Bentuk hubungan jalur Strutural Equation Model seperti terlihat pada Gambar .1 berikut ini: 


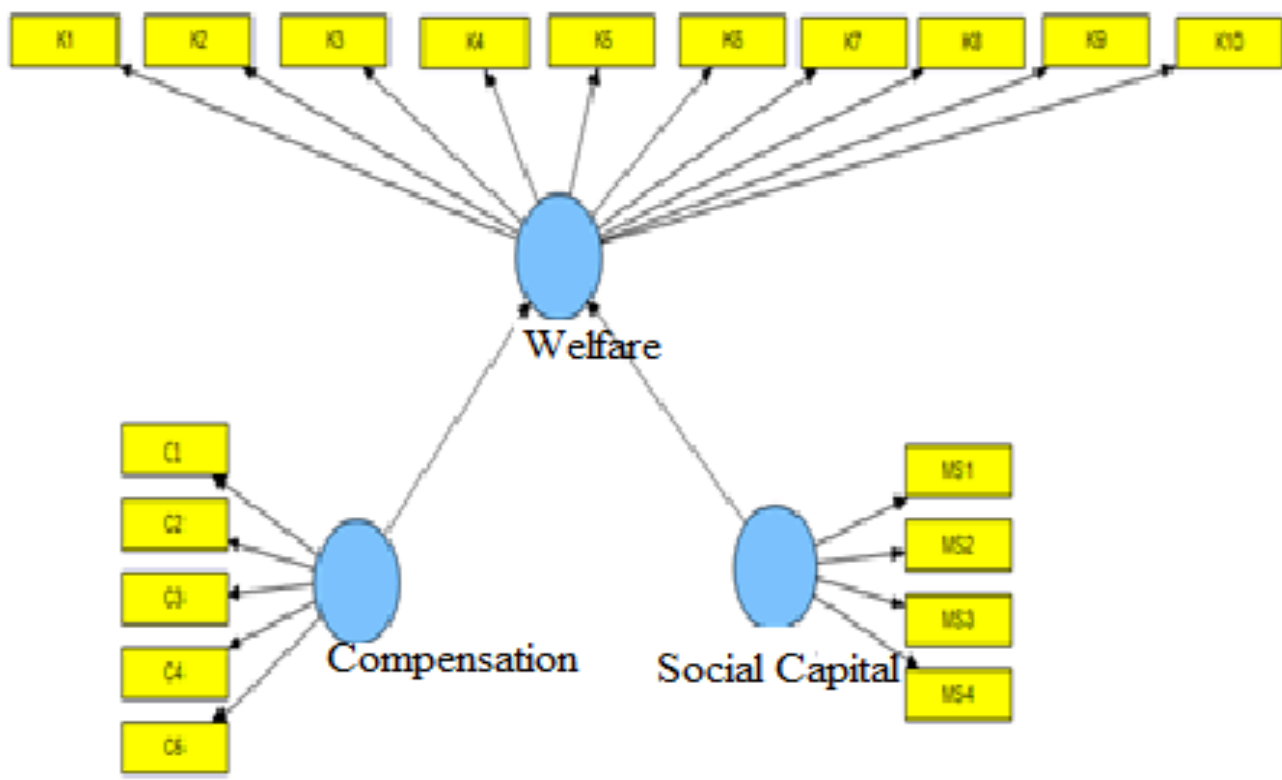

Keterangan:

\begin{tabular}{|c|c|c|}
\hline Laten Variabel & Kode & Manifest Variabel \\
\hline \multirow{10}{*}{ Kesejahteraan } & K1 & Kesehatan \\
\hline & $\mathrm{K} 2$ & pendidikan, \\
\hline & K3 & pekerjaan, \\
\hline & $\mathrm{K} 4$ & pendapatan rumah tangga, \\
\hline & K5 & keharmonisan keluarga, \\
\hline & K6 & ketersediaan waktu luang, \\
\hline & K7 & hubungan sosial, \\
\hline & K8 & rumah dan aset, \\
\hline & K9 & Lingkungan \\
\hline & K10 & keamanan. \\
\hline \multirow{4}{*}{ Modal Sosial } & MS1 & Kepercayaan \\
\hline & MS2 & Kewaspadaan \\
\hline & MS3 & Tolong Menolong \\
\hline & MS4 & Pinjam Meminjam \\
\hline
\end{tabular}




\begin{tabular}{|l|c|l|}
\hline \multicolumn{1}{|c|}{ Laten Variabel } & Kode & \multicolumn{1}{|c|}{ Manifest Variabel } \\
\hline \multirow{4}{*}{ Kompensasi } & $\mathrm{C} 1$ & Uang \\
\cline { 2 - 3 } & $\mathrm{C} 2$ & Luas Bangunan \\
\cline { 2 - 3 } & $\mathrm{C} 3$ & Luas Tanah \\
\cline { 2 - 3 } & $\mathrm{C} 4$ & Luas Lahan Palawija \\
\cline { 2 - 3 } & $\mathrm{C} 5$ & Luas Kebun \\
\hline
\end{tabular}

\section{HASIL DAN PEMBAHASAN}

\section{a. Analisis Kesejahteraan Rumah Tangga Pendekatan Indikator Objektif}

Indikator objektif yang digunakan untuk melihat tingkat kesejahteraan rumah tangga yang dipindahkan adalah tingkat pendapatan. Tingkat pendapatan rumah tangga dalam penelitian ini dihitung berdasarkan pendapatan yang diterima oleh kepala rumah tangga berdasarkan mata pencarian/pekerjaan utama. Secara rata-rata pendapatan rumah tangga responden penelitian adalah $\mathrm{Rp} 1,545$ juta per bulan. Kondisi ini sesuai dengan informasi dan fakta yang ditemui di lapangan bahwa desa Tanjung Balik dan Tanjung Pauh termasuk desa yang kurang berhasil atau tidak sejahtera setelah dipindahkan. Penyebabnya antara lain adalah belum tersedianya lapangan pekerjaan yang memadai untuk memenuhi kebutuhan rumah tangga ditempat baru setelah rumah tangga mengalami pemindahan. Kompensasi yang dijanjikan dalam bentuk kebun karet tidak berhasil, masyarakat juga mengaku bahwa lahan karet yang dijanjikan oleh pemerintah tidak bisa di panen pada waktu yang ditentukan, bahkan banyak yang gagal dan mati. Kondisi ini menurut masyarakat salah satunya karena bibit karet yang ditanam bukanlah bibit unggul. Karena ketidakberhasilan kebun karet maka banyak penduduk di kedua desaini bekerja sebagai buruh pemotong getah karet pada penduduk lain yang memiliki lahan karet yang cukup subur dan berhasil.

Tabel.2Pendapatan Rumah Tangga per Bulan (rupiah)

\begin{tabular}{|c|c|}
\hline Desa/Nagari & Pendapatan \\
\hline Tanjung Balik & $1,555,172$ \\
\hline Tanjung Pauh & $1,535,714$ \\
\hline Rata-rata & 1.545 .443 \\
\hline
\end{tabular}

Sumber: Pengolahan Data Survei, 2018

Secara umum rumah tangga mendominasi pendapatan pada kelompok besar dari Rp 900.000, - Rp 2.400.000,- lebih kurang dari $67 \%$ dan sekitar 33\% rumah tangga yang memiliki pendapatan di bawah Rp 900.000,- rupiah. Kondisi ini memperlihatkan bahwa kesejahteraan rumah tangga yang dipindahkan pada saat ini sudah cukup sejahtera. Jika hal ini diukur dengan indikator kemiskinan BPS (indikator Objektif), dimana ukuran kemiskinan jika pendapatan rumah tangga kurang dari 600 ribu rupiah per bulan.Jika 
dikaji lebih jauh maka kelompok pendapatan rumah tangga dapat dikelompokan sebagai berikut:

Tabel.3Kelompok Pendapatan Rumah Tangga per Bulan (rupiah)

\begin{tabular}{|c|c|}
\hline Pendapatan rata-rata per bulan & $\%$ \\
\hline <= Rp 900.000 & 33 \\
\hline Rp 900.001-1.500.000 & 35 \\
\hline Rp 1.500.001- Rp 2.400.000 & 18 \\
\hline Rp. 2.400.001-Rp 3.600.000 & 6 \\
\hline > Rp. 3.600.000 & 8 \\
\hline Total & 100 \\
\hline
\end{tabular}

Sumber: Pengolahan Data Survei, 2018

b. Analisis Kesejahteraan Rumah Tangga Berdasarkan Indikator Subjektif

Analisis Kesejahteraan Rumah Tangga dengan Indikator Subjektif adalah analisis tingkat kepuasan responden merupakan hasil analisis terhadap persepsi rumah tangga terhadap 10 indikator kesejahteraan. Data persepsi didapatkan dari data kuesioner yang diisi oleh respoden. Informasi atau pertanyaan yang ada pada kuesioner tersebut secara umum adalah pertanyaan yang terkait dengan persepsi kepuasan responden terhadap 10 indikator kebahagiaan. Kuesioner untuk sepuluh indikator tersebut meliputi pertanyaan tentang persepi kepuasan terhadap:kesehatan, pendidikan, pekerjaan, pendapatan rumah tangga, keharmonisan keluarga, ketersediaan waktu luang, hubungan sosial, kondisi rumah dan aset, keadaan lingkungan, kondisi keamanan.

Hasil dari pengolahan data kuesioner terhadap kepuasan rumah tangga (responden) terhadap indikator kebahagiaan tersebut dapat dilihat pada Tabel 4. Tabel tersebut memperlihatkan respon rumah tangga terhadap 10 indikator kebahagian.Masing-masing indikator kebahagiaan di ukur dengan tingkat kepuasan rumah tangga terhadap 10 indikator tersebut. Ukuran subjektif rumah tangga dinyatakan dalam persen.

Tabel 4 menunjukkan bahwa kepuasan responden terhadap pendidikan sangat rendah dan menempati urutan paling rendah diantara 10 indikator kebahagiaan.Sebanyak 9 persen responden rumah tangga menjawab puas dengan kondisi tingkat pendidikan yang mereka miliki saat ini.Kondisi ini menunjukkan bahwa responden menginginkan pendidikan mereka lebih baik dari sekarang.Dengan kata lain, hal ini menunjukkan bahwa secara umum kualitas sumber daya manusia di Koto Panjang masih sangat rendah, sehingga berdampak terhadap tingkat pendapatan yang dimiliki oleh mereka. Pendidikan yang rendah menjadi halangan bagi rumah tangga untuk mendapat pekerjaan.Pekerjaan yang bisa didapatkan sangat terbatas sehingga berdampak terhadap 
penghasilan yang mereka dapatkan.Pendidikan yang rendah cendrung mereka hanya bekerja sebagai buruh atau petani kasar yang menerima upah, tentu saja hasil hanya cukup untuk memenuhi kebutuhan sehari-hari atau bahkan bisa kurang.

Tabel.4Kepuasan Rumah Tangga terhadap Indikator Kesejahteraan di 12 Desa Koto Panjang (dalam persen)

\begin{tabular}{|c|c|c|c|c|c|c|c|c|c|c|}
\hline \multirow{2}{*}{ Desa/Nagari } & \multicolumn{10}{|c|}{ Indikator } \\
\cline { 2 - 15 } & A & B & C & D & E & F & G & H & I & J \\
\hline Tanjung Balik & 25 & 3 & 4 & 13 & 7 & 13 & 30 & 34 & 24 & 27 \\
\hline Tanjung Pauh & 21 & 6 & 8 & 18 & 9 & 15 & 32 & 34 & 31 & 41 \\
\hline Total & 46 & 9 & 12 & 31 & 16 & 28 & 62 & 68 & 55 & 68 \\
\hline
\end{tabular}

Sumber: Pengolahan Data Survei, 2017.

Keterangan :

A).kesehatan, B) pendidikan, C) pekerjaan , D) pendapatan rumah tangga, E) keharmonisan keluarga, F).ketersediaan waktu luang, G) hubungan sosial, H) kondisi rumah dan aset, I) keadaan lingkungan, dan J) kondisi keamanan.

Selanjutnya Tabel 4 juga menunjukkan bahwa kepuasan responden terhadap pekerjaan mereka menempati posisi yang kedua terendah yaitu rata-rata sebanyak 12 persen.Kondisi ini menunjukkan bahwa kepuasan responden terhadap pekerjaan masih rendah.Masyarakat secara umum menganggap pekerjaan mereka yang ada saat ini masih belum seperti yang diharapkan. Kondisi ini bisa menjadi peluang bagi pemerintah untuk mendorong aktivitas masyarakat kepada kegiatan yang produktif.Rumah tangga yang belum puas dengan pekerjaan mereka, bisa dilatih atau dibina untuk mengembangkan diri dengan pelatihan atau pembinaan yang dilakukan oleh pemerintah melalui program-program pemberdayaan msayarakat yang relevan sesuai dengan keinginan dan keahlian yang dimiliki.Pelatihan dan pendidikan yang diberikan oleh pemerintah untuk memberdayakan masyarakat sebaiknya diarahkan pada kegiatan yang tidak memerlukan kemampuan yang spesifik atau pendidikan yang tinggi, karena pendidikan rumah tangga yang ada di Koto Panjang relatif sangat rendah.

Kepuasan rumah tangga di atas 50 persen atau lebih pada penelitian ini ada pada 4 indikator kebahagiaan yaitu hubungan sosial, kondisi rumah dan aset, keadaan lingkungan, dan kondisi keamanan. Hal ini menunjukkan bahwa rumah tangga relatif puas dengan kondisi kesejahteraan mereka terutama dari indikator yang empat ini.Keempat inidikator ini lebih merepresentasikan kondisi non material.

Kepuasan yang relatif tinggi terhadap indikator non material sekaligus menunjukkan bahwa masyarakat merasa sejahtera tidak semata-mata ditentukan oleh materi saja. Sesuai dengan pernyataan Bruno (2008) dan Layard (2006), kesejahteraan bukan hanya ditentukan oleh materi saja tetapi lebih dari itu juga ditentukan oleh indikator lain seperti hubungan dengan tetangga, kondisi lingkungan dan keamanan. Kondisi ini sekaligus menunjukkan bahwa modal sosial seperti keakrabaan, hubungan sosial, keramahan dan tolong menolong diantara rumah tangga involuntary resettlement telah 
memberikan kenyamanan dan kesenangan bagi rumah tangga atau dengan kata lain rumah tangga merasa adanya kebahagiaan yang tidak bisa dinilai dengan materi setelah mengalami masa-masa sulit pada waktu di lokasi lama dan pada masa awal pemindahan ke lokasi pemukiman sekarang. Dengan demikian, selain kepuasan terhadap kondisi rumah dan aset, kesejahteraan non materi ternyata juga berpengaruh cukup besar pada kehidupan seseorang. Hal ini menyimpulkan bahwa pendekatan materi saja tidak bisa menyatakan seseorang menjadi lebih bahagia, perlu pendekatan non materi seperti pendekatan psikologi(Layard, 2006).

\subsection{Analisis Model Struktural Equation Model-Partial Least Square (SEM-PLS).}

Hasil persamaan struktural akhir ini telah melewati pengujian validitas dan reliabilitas sehingga dapat ditemukan model yang baik untuk dianalisis. Hasil persamaan struktural akhir dapat dilihat pada gambar analisis jalur (Path Analysis). Analisis jalur dapat mengungkapkan pengaruh langsung dan pengaruh tidak langsung antar konstruk.

\section{Gambar.2Diagram Jalur SEM}

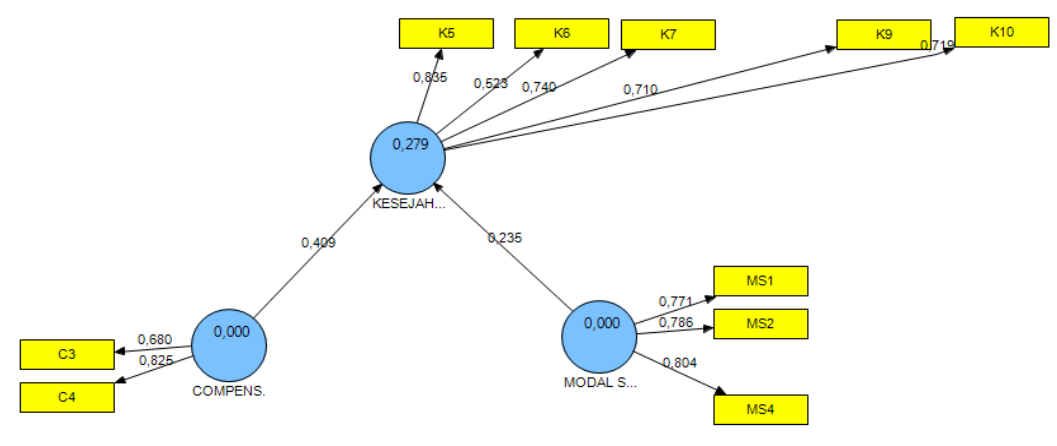

Sumber: Hasil Olahan Data menggunakan PLS, 2017.

Keterangan :

\begin{tabular}{|c|c|l|}
\hline \multirow{2}{*}{ Variabel Laten } & Kode & \multicolumn{1}{|c|}{ Indikator } \\
\hline \multirow{2}{*}{ Kesejahteraan } & K5 & keharmonisan keluarga, \\
\cline { 2 - 3 } & K6 & ketersediaan waktu luang, \\
\cline { 2 - 3 } & K7 & hubungan sosial, \\
\cline { 2 - 3 } & K9 & Lingkungan \\
\hline
\end{tabular}




\begin{tabular}{|l|c|l|}
\hline \multirow{2}{*}{ Kompensasi } & K10 & Keamanan \\
\hline \multirow{2}{*}{ Modal Sosial } & C3 & Luas Tanah \\
\cline { 2 - 3 } & C4 & Luas Lahan Pertani \\
\hline \multirow{2}{*}{} & MS1 & Kepercayaan \\
\cline { 2 - 3 } & MS2 & Kewaspadaan \\
\cline { 2 - 3 } & MS3 & Tolong Menolong \\
\hline
\end{tabular}

Berdasarkan hasil analisis diagram jalur di atas dapat ketahui bahwa ada dua variabel yang mempengaruhi Kesejahteraan Masyarakat yaitu Kompensasi dan Modal Sosial. Selanjutnya sebelum menganalis hubungan masing-masing variabel dalam penelitian ini, langkah berikutnya terlebih dahulu yang harus dilakukan adalah menguji hipotesis. Uji hipotesis sangat menetukan apakah suatu variabel laten atau konstruk perlu dianalisis atau tidak. Jika hasil uji hipotesis menunjukkan bahwa suatu variabel tidak signifikan maka variabel tersebut tidak layak dianalis lebih lanjut walaupun hubungan yang didapat sesuai dengan teori.

Tabel.5 Uji Hipotesis

\begin{tabular}{|l|c|c|c|c|c|}
\hline \multicolumn{1}{|c|}{ Kausalitas } & $\begin{array}{c}\text { Original } \\
\text { Sample (O) }\end{array}$ & $\begin{array}{c}\text { Sample } \\
\text { Mean } \\
(\mathrm{M})\end{array}$ & $\begin{array}{c}\text { Standard } \\
\text { Deviation } \\
\text { (STDEV) }\end{array}$ & $\begin{array}{c}\text { Standard } \\
\text { Error } \\
\text { (STERR) }\end{array}$ & $\begin{array}{c}\text { T Statistics } \\
(\text { |O/STERR|) }\end{array}$ \\
\hline $\begin{array}{l}\text { Kompensasi -> } \\
\text { Kesejahteraan }\end{array}$ & 0,409142 & 0,454461 & 0,083175 & 0,083175 & 4,919020 \\
\hline $\begin{array}{l}\text { Modal Sosial -> } \\
\text { Kesejahteraan }\end{array}$ & 0,235397 & 0,222025 & 0,156806 & 0,156806 & 1,501199 \\
\hline
\end{tabular}

Sumber: Pengolahan Data menggunakan PLS, 2017

${ }^{*} \alpha=5 \%$,

Uji hipotesis dalam model ini dilakukan dengan membandingan t-tabel dengan tstatistik, jika t-statistik lebih besar dari t-tabel maka variabel yang digunakan layak untuk dianalisis atau digunakan dalam penelitian ini. Hasil uji hipotesis model SEMPLS tersebut dapat dilihat pada Tabel 5

Hasil uji hipotesis pada Tabel 5 memperlihatkan bahwa variabel kompensasi berpengaruh positif dan signifikan $(\alpha=5 \%)$ terhadap kesejahteraan masyarakat. Sedangkan variabel modal sosial tidak terbukti dalam penelitian ini berpengaruh secara signifikan karena nilai t-hitung lebih rendah dari nilai t-tabel.Hasil ini menyimpulkan bahwa hanya variabel kompensasi yang berpengaruh terhadap kesejahteraan masyarakat dalam penelitian ini.

Interpretasi dari hasil akhir model ini adalah bahwa semakin tinggi semakin besar atau semakin baik Kompensasi yang diterima oleh responden maka akan semakin meningkat kesejahteraan masyarakat. Interpretasi ini sekaligus menjawab hipotesis penelitan bahwa kompensasi berpengaruh positif dan signifikan terhadap kesejahteraan 
masyarakat.Sedangkan hipotesis lainnya yaitu modal sosial berpengaruh positif dan signifikan terhadap kesejahteraan masyarakat tidak terbukti.

Pada variabel kompensasi yang digunakan sebagai indikator (variabel manifes) adalah luas lahan palawija dan luas lahan perkebunan. Hal ini menunjukkan bahwa dari 5 indikator kompensasi yang dimasukan dalam model SEM-PLS yaitu uang, luas bangunan, luas tanah, luas lahan palawija dan luas lahan perkebunan ternyata luas tanah dan luas lahan palawija ( 2 indikator) yang bisa digunakan sebagai alat analisis mewakili kompensasi. Dengan demikian dapat dijelaskan bahwa untuk memperbaiki kesejahteraan masyarakat maka pemerintah perlu memberi perhatian khusus terhadap keberlanjutan penggunaan lahan palawija dan lahan pertanian yang dimiliki masyarakat. Dari hasil survei dilapangan terbukti bahwa rumah tangga yang mampu mengolah dan menggunakan lahan pertanian menjadi lahan palawija dengan baik akan mendapat penghasilan yang baik pula. Lahan palawija bisa dipergunakan sebagai lahan untuk kegiatan ekonomi produktif, bisa dioleh menjadi lahan pertanian, perikanan atau usaha produktif lainnya untuk menghasilkan pendapatan.

Selanjutnya lahan perkebunan, tidak bisa digunakan sebagai manifes atau indikator dalam penelitian ini anatra lain disebabkan tidak berhasilnya lahan karet dalam menunjang peningkatan kesejahteraan rumah tangga, kondisi ini bisa terjadi karena bibit karet yang ditanam tidak berhasil, banyak bibit karet yang tidak tumbuh dengan baik bahkan mati. Berbeda dengan daerah lain yang juga termasuk rumah tangga pindah akibat pembangunan bendungan Koto Panjang yang lebih sukses dengan kebun sawit karena tumbuh dengan subur sehingga kesejahteraan rumah tangga meningkat, daerah tersebut antara lain Mayang Pongkai dan Muaro Mahat

\section{KESIMPULAN}

Kesimpulan dari penelitian ini adalah:

a. Hasil penelitian menunjukkan bahwa secara umum kesejahteraan rumah tangga yang dipindahkan paksa (involuntary resettlement) di Nagari Tanjung Balik dan Tanjung Pauh Koto Panjang, saat ini meningkat dibandingkan dengan kondisi rumah tangga sebelum pindah dari lokasi lama maupun pada masa awal pemindahan. Hasil penelitian dengan menggunakan indikator objektif (indikator pendapatan) menunjukkan bahwa pendapatan rumah tangga meningkat dari sebelumnya.

b. Analisis menggunakan indikator subjektif (10 indikator kebahagiaan) menunjukkan bahwa kepuasan rumah tangga terhadap indikator hubungan sosial, keadaan lingkungan, dan kondisi keamanan lebih dari diatas 50 persen. Hasil ini sekaligus menunjukkan bahwa kesejahteraan rumah tangga atau masyarakat tidak hanya tergantung dengan pemenuhan kebutuhan materi saja, tetapi lebih dari itu faktor non materi lebih mendominasi seseorang untuk lebih sejahtera.

c. Hasil analisis dari model SEM-PLS menunjukkan hanya variabel kompensasi berpengaruh positif dan signifikan terhadap kesejahteran masyarakat. Hal ini mengindikasikan bahwa untuk meningkatkan kesejahteraan masyarakat, hal yang sangat penting harus diperhatikan pemerintah adalah bagaimana supaya kompensasi atau ganti rugi yang diterima masyarakat harus dijaga keberlanjutannya, karena kompensasi yang diterima ini lebih cendrung dalam 
bentuk lahan atau sumber daya produktif, dan sekaligus merupakan sumber penghidupan yaitu lahan palawija dan kebun.

\section{E. DAFTAR PUSTAKA}

.ADB. (1995). Involuntary Resettlement. Dikutip dari :

http://www.adb.org/sites/default/files/institutionaldocument/32515/files/involu ntay-resettlement.pdf

Amiany., Sahay, N. S. (2011). Kajian Permukiman Kembali PendudukTepian Sungai Kahayan di Kota Palangkaraya, Jurnal Arsitektur. Volume 6 Nomor 1 Juli 2011 ISSN 1412 - 338.

Andrianus, F (2016). Involuntary Resettlement: Solusi atau Bencana, Makalah Konfrensi Nasional V APSSI, Padang 17-19 Mei 2016.

Asthana, R. (1996). Involuntary Resettlement: Survey of International ExperienceSource: Economic and Political Weekly, Vol. 31, No. 24 pp 14681475http://www.jstor.org/stable/4404268.

Bruno, F. (2008). Happiness: A Revolution in Economics, https://mitpress.mit.edu/sites/default/files/9780262514958_sch_0001_0.pdf

Cahyono, B., Adhiatma, A. (2012). Peran Modal Sosial Dalam Peningkatan Kesejahteraan Masyarakat Petani Tembakau Di Kabupaten Wonosobo, Proceedings of Conference In Business, Accounting and Management (CBAM) 2012. Vol. 1 No1. Fakultas Ekonomi Universitas Islam Sultan Agung.

Cernea, M. M. (2004). Impoverishment Risks, Risk Management, and Reconstruction: A Model of Population Displacement and Resettlement. The UN Symposium on Hydropower and Sustainable Development.Beijing, October 27-29.

Ghozali, I . (2008) Structural Equation Modeling Metode Alternatif dengan Partial Least Square. Universitas Diponegoro. ISNB : 979.704.250.9

JBIC (2004). Kota Panjang Hydroelectric Power and Associated Transmission Line Project (1) (2): Third Party Ex-Post Evaluation Report. Japan Bank for International Corporation (JBIC).

Karimi, S., Taifur, D. W. (2013). Resettlement and development: a survey of two of Indonesia's Koto Panjang resettlement villages. International Journal of Water Resources Development.Vol. 29, No. 1, March 2013, 32-46

Kementrian PU. (2011). Executive Summary : Penyusunan Model Perhitungan Pembebasan lahan, Relokasi \& Pemukiman Kembali Penduduk dalam Pembangunan Waduk.

http://www.pu.go.id/uploads/services/infopublik20130502125605.pdf

Layard, R. (2006). Happiness and Public Policy: a Challenge to the Profession The Economic Journal 116, C24-C33. 
Noor., J. (2014). Analisis Data Penelitian Ekonomi dan Manajemen, Grasindo, Jakarta.

Uslaini, Purwanto, W. (2015). Skema Pembiayaan Infrastruktur yang Bersandar pada Investasi Asing; Mengulang Kesalahan Krisis Tahun 80an: Studi Kasus Dam Koto Panjang. "Dilema Nawa Cita dan Lingkungan yang Berkelanjutan Pemerintahan Jokowi - JK”.Jurnal Tanah Air.Walhi. Edisi Agustus

World Bank (2000). Involuntary Resettlement: The Large Dam Experience. Precis 194.

Winter, Ian., (2000). Towards a theorizedUnderstanding of Family Life and Social Capital, Working Paper No. 21 Australian Institute of Family Studies, $300 \quad$ Queen $\quad$ Street, Melbourne, Victoria 3000, Australia.

Wilcox., D, (1994). A Guide to Effective Participation, York, Joseph Rowntree Foundation.https://phobos.ramapo.edu/ vasishth/Readings/WilcoxGuide_To_Ef fective_Participation.pdf

Yasuyuki, K. (1998). Dampak Sosial Akibat Pemindahan Penduduk (Studi Kasus: Desa Tigo Koto Tanjung Pauh di Sumatera Barat). Tesis Magister. Program Sosiologi Pedesaan. Pascasarjana IPB. 